\title{
Carcinoma Espinocelular do Pénis
}

\section{Penile Squamous Cell Carcinoma}

\author{
Ermelindo TAVARES $\square^{1}$, Margarida RATO ${ }^{1}$, Helena GOMES ${ }^{2}$ \\ Acta Med Port 2016 Jun;29(6):417-417 - http://dx.doi.org/10.20344/amp.7090
}

Palavras-chave: Carcinoma de Células Escamosas; Neoplasias do Pénis.

Keywords: Carcinoma, Squamous Cell; Penile Neoplasms.
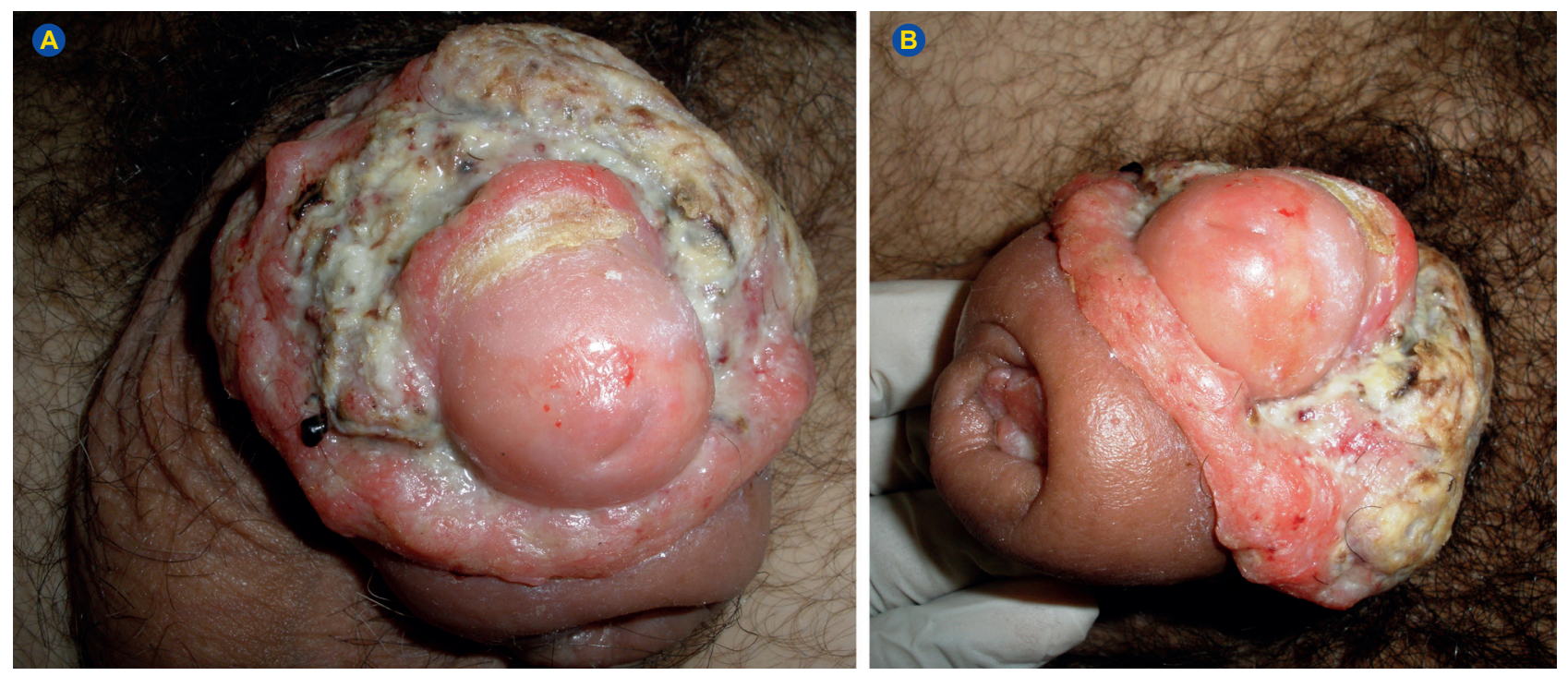

Figura 1 - Carcinoma espinocelular do pénis. Massa tumoral volumosa, ulcerada e pétrea, ocupando 70-80\% do corpo peniano. Deformidade marcada do órgão, condicionando desvio superior da glande para fora do prepúcio (ectopia balánica).

Homem de 54 anos, observado por lesão peniana com dois meses. Antecedentes venereológicos irrelevantes. Micção mantida. Exame objetivo demonstrou tumor corporal volumoso (10 cm maior eixo), ulcerado, pétreo, indolor, com exsudado purulento de odor pútrido, invasão cavernosa e deformidade peniana (Fig 1). Palpava-se adenopatia inguinal bilateral, móvel, com $2 \mathrm{~cm}$. Restante avaliação física irrelevante. Revisão analítica insignificante. Tomografia computorizada (tórax, abdómen e pelve) mostrou apenas um gânglio metastático ilíaco externo bilateral. Realizouse penectomia parcial e linfadenectomia inguinal bilateral radical. Histologia revelou carcinoma espinocelular (CEC) bem diferenciado (margens negativas, sem efeito citopático), e um gânglio metastático. Seis anos depois encontrase sem recidiva (local, regional, à distância).

O CEC é o cancro peniano mais comum. ${ }^{1} \mathrm{O}$ envolvimento do corpo é raro. ${ }^{1,2}$ São fatores de risco idade avançada, ausência de circuncisão, fimose, trauma, balanite crónica, vírus do papiloma humano e tabagismo. ${ }^{1-5} \mathrm{~A}$ cirúrgica constitui a principal modalidade terapêutica nos tumores

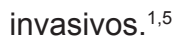

\section{REFERÊNCIAS}

1. Vilhena-Ayres JA. Carcinoma of the penis. The basic principles of the diagnostic and therapeutic guidelines. Acta Med Port. 1999;12:95-7.

2. Hernandez BY, Barnholtz-Sloan J, German RR, Giuliano A, Goodman MT, King JB, et al. Burden of invasive squamous cell carcinoma of the penis in the United States, 1998-2003. Cancer. 2008;113:2883-91.

3. Clark PE, Spiess PE, Agarwal N, Biagioli MC, Eisenberger MA, Greenberg RE, et al. Penile cancer: Clinical Practice Guidelines in Oncology. J Natl Compr Canc Netw. 2013;11:594-615.

4. Madsen BS, van den Brule AJ, Jensen HL, Wohlfahrt J, Frisch M. Risk factors for squamous cell carcinoma of the penis-population-based case-control study in Denmark. Cancer Epidemiol Biomarkers Prev. 2008;17:2683-91.

5. Pow-Sang MR, Ferreira U, Pow-Sang JM, Nardi AC, Destefano V. Epidemiology and natural history of penile cancer. Urology.2010;76:S2-6.

\footnotetext{
1. Serviço de Dermatologia e Venereologia. Hospital de Santarém. Santarém. Portugal.

2. Serviço de Urologia. Hospital de Santarém. Santarém. Portugal.

$\square$ Autor correspondente: Ermelindo Tavares. tavares.ermelindo@gmail.com

Recebido: 13 de outubro de 2015 - Aceite: 29 de dezembro de 2015 | Copyright @ Ordem dos Médicos 2016
} 